\title{
Prevalence of Anemia Among Children in a Single University Hospital
}

Neslihan Karakurt $\odot$ Özlem Terzi ${ }^{\oplus}$

\author{
Bir Üniversite Hastanesinde Çocuklarda Anemi \\ Prevalansı
}

\begin{abstract}
Objective: Anemia is a common public health issue, causing an increase in mortality and morbidity, especially in pregnant women and children. WHO reported the prevalence of anemia in preschool children as $47.4 \%$, and incidence of anemia is gradually increasing. Iron deficiency is responsible for approximately $50 \%$ of cases with anemia. This study aims to determine the prevalence of anemia and the underlying causes of anemia in pediatric patients who were admitted to a reference hospital.

Method: This cross-sectional study was planned retrospectively and children between 0.5-15 years of age who were admitted to our hospital for any indication between July 2017-July 2018 were included. Sampling Among these patients with anemia, those with hemoglobin values less than $11 \mathrm{~g} / \mathrm{dl}$ were included in the study.

Results: The incidence of anemia was detected as $8.2 \%(n=4655)$. The median age of anemic children was three years, and $54.4 \%$ of them were male. Anemia was more common among 2-5 year-old-children (50.8\%). The prevalence of anemia was higher in boys between ages of 0.5-1 and 2-5 years, while it was higher in girls between ages of 10-12 and 13-15 years with a statistically significant difference. The median hemoglobin value was 10.2 (min-max: 2.8-10.9) g/dl, and MCV was 74.5 (min-max: 46.9-126.8) fl. Conclusion: The incidence of anemia in a reference centre in Black Sea region of Turkey in children between $0.5-15$ years of age is $8 \%$. The laboratory parameters were consistent with a probable diagnosis of iron deficiency anemia. The majority of patients (64\%) had mild anemia. Collaboration between physicians and parents in the prevention and treatment of anemia is critical in protecting children from anemia, which is the cause of preventable mental retardation.
\end{abstract}

Keywords: Anemia, pediatrics, public health

öz

Amaç: Anemi özellikle gebelerde ve çocuklarda mortalite ve morbidite artışına yol açan yaygın bir halk sağlığı sorunudur. Dünya Sağık Örgütü, dünya genelinde okul öncesi çocuklarda anemi prevalansını \%47,4 olarak bildirmiştir ve anemi insidansı giderek artmaktadır. Anemisi olan olguların yaklaşık \%50'sinden demir eksikliği sorumludur. Bu çalışmada, referans hastaneye başvuran pediatrik hastalarda anemi prevalansı ve nedenlerinin belirlenmesi amaçlanmıştır.

Yöntem: Bu kesitsel çalışma retrospektif olarak planlanmış olup, evrenini Temmuz 2017 ile Temmuz 2018 tarihleri arasında, hastanemize herhangi bir nedenle başvuran ve tam kan sayımı yapılan 6 ay-15 yaş arasındaki çocuklar oluşturmuştur. Örnekleme bu hastalardan anemik olanlar, yani hemoglobin değeri 11 g/dl'den küçük olanlar dahil edilmiştir.

Bulgular: Anemi insidansı \%8,2 (n=4655) saptanmıştır. Anemik çocukların ortanca yaşı 3 yıl olup, \%54,4'ü erkektir. Yaş gruplarına göre dağılımları incelendiğinde, en sık 2-5 yaş arası $(\% 50,8)$ çocuklarda anemi olduğu belirlenmiştir. 0,5-1 yaş ve 2-5 yaş gruplarında erkek çocuklarında anemi sıklığı daha yüksekken, 10-12 ve 13-15 yaş gruplarında ise kız çocuklarında daha yüksektir ve bu fark istatistiksel olarak anlamlıdır. Anemik çocukların ortanca hemoglobin değeri 10,2 (min-max: 2,8-10,9) g/dl ve MCV 74,5 (min-max: 46,9126,8) fl saptanmıştır.

Sonuç: Karadeniz bölgesinde bir referans hastanede 0,5-15 yaş aralığında anemi sıklığını \%8 saptanmış olup, laboratuvar bulguları olası bir demir eksikliği anemisi tanısı ile uyumlu olarak değerlendirildi. Hastaların büyük çoğunluğunda (\%64) hafif anemi saptandı. Hekimlerin anemiyi önleme ve tedavi etme konusunda hasta ailesiyle işbirliği içinde çalışması ve aileleri bilinçlendirmesi, çocuklarda önlenebilir bir zeka geriliği nedeni olan anemiden korunmada çok büyük önem göstermektedir.
Alındığı tarih: 21.01 .2019

Kabul tarihi: 05.04.2019

Yayın tarihi: 26.07.2019

Neslihan Karakurt Ondokuz Mayıs Üniversitesi Tıp Fakültesi Hastanesi, Çocuk Hematoloji Bölümü, Samsun - Türkiye neslihan.karakurt@omu.edu.tr ORCiD: 0000-0001-5487-9485

\section{Ö. Terzi 0000-0002-9524-5582 Ondokuz Mayıs Üniversitesi Tıp Fakültesi, Halk Sağlığı ABD,} Samsun, Türkiye

Anahtar kelimeler: Anemi, pediatri, halk sağığı

(c) Telif hakkı İzmir Dr. Behçet Uz Cocuk Hastalıkları ve Cerrahisi Eğitim ve Araștırma Hastanesi'ne aittir. Logos Tıp Yayıncılık tarafindan yayınlanmaktadır. Bu dergide yayınlanan bütün makaleler Creative Commons Atf-GayriTicari 4.0 Uluslararası Lisansı ile lisanslanmıştır. 


\section{INTRODUCTION}

According to the World Health Organization (WHO) data, anemia is a common public health issue, causing an increase in mortality and morbidity, especially in pregnant women and children. Anemia affects 2.5 billion people on a worldwide basis. WHO reported that the prevalence of anemia in preschool children is $47.4 \%{ }^{(1)}$ and the incidence of anemia has increased ${ }^{(1,2)}$. Iron deficiency is responsible for approximately $50 \%$ of the cases with anemia ${ }^{(1,2)}$. Iron deficiency anemia in infancy and early childhood has negative consequences on growth and development if not treated.

Regular follow-up of children has a vital role in the diagnosis and treatment of anemia. In 2004, in order to reduce the incidence of iron deficiency anemia in Turkey, Ministry of Health launched a project named "Iron-like Turkey" (3). In this project, it is aimed to provide prophylactic iron support to children between 4-12 months of age and to detect and treat anemia at an early period of life, between 12-23 months of age ${ }^{(3)}$. However, in our country where iron-rich diet has found a limited use, iron deficiency anemia is still an important public health problem despite the health policies implemented.

According to the data of the World Health Organization (WHO) the prevalence of anemia in childhood is 30 percent ${ }^{(2)}$. Anemia prevalence studies were performed in different provinces of Turkey. In prevalence studies performed in different parts of our country such as Istanbul, Sivas, Trabzon, Denizli (4-7), the frequency of anemia has been reported to range between 6-46 percent. In a study in Samsun, involving school-age children (7-14 years), the prevalence rates of anemia, and iron deficiency have been reported as $9 \%$, and $26 \%$,respectively ${ }^{(8)}$.

This study was performed in a university hospital which is an important reference center that undertakes treatment of many patients. This study aims to determine the prevalence of anemia and the underlying causes of anemia in pediatric patients who were admitted to the reference hospital.

\section{MATERIALS and METHODS}

This cross-sectional study was planned retrospectively and children between ages of 6 months to 15 years who were admitted to our hospital for any indication and their complete blood counts were evaluated between July 2017 and July 2018 were included in the study. Patients aged between 6 months, and 2 years with hemoglobin levels below $10.5 \mathrm{~g} / \mathrm{dl}$, and older children with hemoglobin values less than $11 \mathrm{~g} / \mathrm{dl}$ were included in the study. Repetitive data were excluded, and the results at the first admission date were taken into consideration. Data of patients, such as age, gender, complete blood count values, comorbidities, were obtained from patients' hospital records. The diagnosis was based on the international classification of diseases (ICD-10).

According to WHO's definition of anemia, hemoglobin values less than $11 \mathrm{~g} / \mathrm{dl}$ were considered as anemia ${ }^{(9)}$. Patients with hemoglobin values of $10.0-11.0 \mathrm{~g} / \mathrm{dl}, 9.9-7.0 \mathrm{~g} / \mathrm{dl}$, and $<6.9 \mathrm{~g} / \mathrm{dl}$ were classified in categories of mild, moderate, and severe anemia ${ }^{(9)}$.

Ethics committee approval and institution permissions were obtained. As the study had a retrospective (archive screening) design, it was not seen necessary to obtain consent from the patients and their relatives.

After the data obtained from the research were coded, it was transferred to SPSS (Version 22 for Windows, SPSS Inc., Chicago, IL, USA) package program and analyzed. When data were evaluated, parametric variables were expressed by the mean \pm standard deviation, while the non-parametric variables were expressed in median (minimum and maximum) (min-max) values. Frequency data were expressed by numbers and percentagse (\%). In statistical analysis, the chi-square test was used to compare frequency data. The Kolmogorov-Smirnov test examined the suitability of the variables to the normal distribution. For data with non-normal distribution, the paired comparisons were performed using the Mann Whitney $U$ test. The statistical significance level for all tests was accepted as $p<0.05$. 


\section{RESULTS}

A total of 56713 patients between the ages of six months and 15 years were admitted to our hospital during the twelve month-period specified in the study. The female/male ratio was 30833 (54.3\%) /25880 (45.7\%). All patients ( $n=4655 ; 8.2 \%)$ with anemia were included in the study. The median age of anemic children was three years (min-max: 0-15), and $54.4 \%$ of them were male. Anemia was most commonly (50.8\%). encountered in the age group of 2-5-years The comparison of age groups by gender is shown in Table 1.

The prevalence of anemia was higher in boys in the age group of $0.5-1$ years and 2-5 years, while it was higher in girls between 10-12 and 13-15 years of age, and the difference was statistically significant $(p<0.00001)$.

The median hemoglobin value of anemic children was 10.2 (min-max: 2.8-10.9) $\mathrm{g} / \mathrm{dl}$ and the mean erythrocyte volume (MCV) was 74.5 (min-max: 46.9126.8) fl (Table 2).

When the age groups of the patients were classi-

Table 1. Distribution of ages of children with anemia according to gender.

\begin{tabular}{lccc}
\hline & $\begin{array}{c}\text { Total } \\
\mathbf{n}(\%)\end{array}$ & $\begin{array}{c}\text { Male } \\
\mathbf{n}(\%)\end{array}$ & $\begin{array}{c}\text { Female } \\
\mathbf{n}(\%)\end{array}$ \\
\hline 6 months- 1 year old & $929(20.0)$ & $529(56.9)$ & $400(43.1)$ \\
2-5 years old & $2367(50.8)$ & $1355(57.2)$ & $1012(42.8)$ \\
6- 9 years old & $681(14.6)$ & $353(51.8)$ & $328(48.2)$ \\
10-12 years old & $313(6.7)$ & $150(47.9)$ & $163(52.1)$ \\
13-15 years old & $365(7.8)$ & $143(39.2)$ & $222(60.8)$ \\
Total & $4655(100.0)$ & $2530(54.4)$ & $2125(45.6)$ \\
& & & \\
\hline
\end{tabular}

*Percent of columns

Table 2. Complete blood count parameters of children with anemia.

\begin{tabular}{lc}
\hline & Median (min-max) \\
\hline Hemoglobin (g/dl) & $10.2(2.8-10.9)$ \\
WBC count (thousands/ul) & $9.0(0.10-236.80)$ \\
PLT (thousands/ul) & $334.0(100.0-3694.0)$ \\
MCV (fl) & $74.5(46.9-126.8)$ \\
RBC (millions/ul) & $4.3(0.88-7.15)$ \\
MCHC (g/dl) & $33.0(22.9-39.6)$ \\
\hline
\end{tabular}

fied according to hemoglobin levels, the most common hemoglobin values measured were between $10-11 \mathrm{~g} / \mathrm{dl}$ (mild anemic) in all age groups. However, there was no statistically significant difference between age groups regarding anemia $(\mathrm{p}=0.18)$ (Table 3$)$.

Patients had received diagnoses of iron deficiency anemia ( $n=1298 ; 28 \%)$, acute leukemia ( $n=1182$; $3 \%)$, hemolytic anemia ( $n=179 ; 3.4 \%)$ and aplastic anemia $(n=23 ; 0.4 \%)$. A total of 3037 (65\%) of the patients who were anemic according to laboratory results did not have any ICD-10 diagnosis for anemia. These 3037 children, $(n=2023)$ had hemoglobin values between 10-11 g/d ( $\mathrm{n}=2023 ; 66.6 \%), 7-9 \mathrm{~g} / \mathrm{dl}$ $(\mathrm{n}=925 ; 30.5 \%)$ and below $7 \mathrm{~g} / \mathrm{dl}(\mathrm{n}=89 ; 2.9 \%)$, respectively .

A total number of 262 (5.6\%) patients had severe anemia $(<7.0 \mathrm{~g} / \mathrm{dl})$, and $56.9 \%$ of these patients were male, but no statistically significant difference was found between genders among non-severe anemic

Table 3. Distribution of level of anemia according to the age of children.

\begin{tabular}{|c|c|c|c|c|c|c|c|}
\hline & \multicolumn{6}{|c|}{ Hemoglobin level } & \multirow[b]{3}{*}{$\mathbf{p}$} \\
\hline & \multicolumn{2}{|c|}{$10.0-11.0 \mathrm{~g} / \mathrm{dl}$} & \multicolumn{2}{|c|}{$9.9-7.0 \mathrm{~g} / \mathrm{dl}$} & \multicolumn{2}{|c|}{$<7.0 \mathrm{~g} / \mathrm{dl}$} & \\
\hline & $\mathbf{n}$ & $(\%) *$ & $\mathbf{n}$ & $(\%)^{*}$ & $\mathbf{n}$ & $(\%) *$ & \\
\hline $\begin{array}{l}6 \text { months-1 } \\
\text { year old }\end{array}$ & $577^{* *}$ & $(62.1)$ & 307 & (33.0) & 45 & $(4.8)$ & \\
\hline 2- 5 years old & 1536 & $(64.9)$ & 706 & $(29.8)$ & 125 & (5.3) & \\
\hline 6- 9 years old & 448 & (65.8) & 190 & (27.9) & 43 & (6.3) & 0.18 \\
\hline $10-12$ years old & 195 & $(62.3)$ & 98 & (31.3) & 20 & (6.4) & \\
\hline $13-15$ years old & 230 & (63.0) & 106 & (29.0) & 29 & (7.9) & \\
\hline Total & 2986 & (64.1) & 1407 & $(30.2)$ & 262 & (5.6) & \\
\hline
\end{tabular}

*Percent of row

**Hemoglobin level is 10.0-10.5 for this group

Table 4. Distribution of age groups of children with severe anemia according to gender.

\begin{tabular}{lccccccc}
\hline & \multicolumn{2}{c}{ Total } & \multicolumn{2}{c}{ Male } & \multicolumn{2}{c}{ Female } & \\
\cline { 2 - 6 } & $\mathbf{n}$ & $\mathbf{( \% )}$ & $\mathbf{n}$ & $\mathbf{( \% )}$ & $\mathbf{n}$ & $\mathbf{( \% )}$ & $\mathbf{p}$ \\
\hline 6 months-1 & 45 & $(17.2)$ & 27 & $(60.0)$ & 18 & $(40.0)$ & \\
year old & 125 & $(47.7)$ & 73 & $(58.4)$ & 52 & $(41.6)$ & \\
2-5 years old & 43 & $(16.4)$ & 19 & $(44.2)$ & 24 & $(55.8)$ & \\
6-9 years old & 20 & $(7.6)$ & 15 & $(75.0)$ & 5 & $(25.0)$ & 0.19 \\
10-12 years old & 29 & $(11.1)$ & 15 & $(51.7)$ & 14 & $(48.3)$ & \\
13-15 years old & 262 & $(100.0)$ & 149 & $(56.9)$ & 113 & $(43.1)$ & \\
Total & & & & & & & \\
\hline
\end{tabular}

*Percent of column 
patients $(p>0.05)$. The median age of the severely anemic patients was four years (min-max: 0-15), which was significantly higher than the mean age of all patients with anemia $(p=0.02)$. There was no statistically significant difference in patients with severe anemia as for age groups.

When the patients diagnosed with severe anemia were evaluated according to the diagnoses defined in ICD-10, the indicated number of patients were in the categories of "anemia, unspecified" ( $n=35$; 13.4\%), "aplastic anemia", ( $n=10 ; 3.8 \%)$, and "iron deficiency anemia" ( $n=21 ; 8.0 \%)$, "hemolytic anemia" ( $n=20 ; 7.6 \%)$, and "megaloblastic anemia ( $n=6$; $2.3 \%)$. Other diagnoses were as follows in order of decreasing frequency; chronic diseases in 77 (29.4\%), malignancies in $49(18.7 \%)$, trauma (accidents and intoxications) in 22 (8.4\%) and infectious diseases in $22(8.4 \%)$ patients. Patients with severe anemia and chronic disease $(n=77)$ had neurological diseases $(n=28 ; 36.6 \%)$, cardiovascular disease $(n=10 ; 13.0 \%)$ endocrinological disease, $(n=7 ; 9.1 \%)$ and metabolic disease ( $n=6 ; 7.8 \%)$. Of 49 patients with malignancy), $20(40.8 \%)$ patients had acute lymphoblastic leukemia, and 19 (38.7\%) had solid tumors.

\section{DISCUSSION}

Anemia is common in children and is still considered to be a public health issue in our country. The incidence of anemia varies according to age, socioeconomic conditions. In this study, we aimed to find the frequency of anemia among patients who were admitted to a reference university hospital in the Black Sea Region. The incidence of anemia among children admitted to Children's Hospital in one year was found as $8.2 \%$. Prevalence rates of anemia in our country have been reported to range between 4 and 7 percent. We think that iron prophylaxis, which is accepted for the prevention of anemia worldwide, and free iron preparations to be given to infants within the scope of the project "Iron-like Turkey" (3) especially in our country, had a significant contribution to the reduction of the prevalence of anemia.

Median hemoglobin value of the patients included in the study was $10.2 \mathrm{~g} / \mathrm{dl}$, and median MCV value was $74.5 \mathrm{fl}$, which are consistent with a probable diagnosis of iron deficiency anemia. The majority of patients $(64 \%)$ had mild anemia. The low frequency of anemia and the fact that the majority of anemic patients have mild anemia can be considered as positive findings.

In this study, anemic patients were most frequently aged between $2-5(n=2367,50.8 \%)$ and $0.5-1$ years ( $n=929,20.0 \%)$, respectively. As anticipated, anemia is seen more frequently in the preschool period where faster growth rates are seen. Besides, in this age group, children depend on adults for their nutrition, and experience frequent infections in kindergarten which also contributes to anemia. In his thesis in 2008, Eren et al. ${ }^{(10)}$ found that anemia was most common in the preschool period and age of 0-1 years.

Anemia was statistically significantly more frequent in girls during adolescence period (10 years and older) in our study. It is expected that iron deficiency anemia is a consequence of failure to meet the increasing need for iron in both genders during the adolescent period, and especially in this period, the preference of "fast food" consumption leads to inadequate iron intake. Also, anemia can be seen more frequently in girls due to the menarche and irregular menstrual bleeding.

When patients were classified according to the ICD-10 diagnostic codes, $65 \%$ had no anemia-related diagnosis, and the majority (66\%) of these patients had mild anemia. In other words, the rate of anemia is very high in patients who were admitted to our hospital for any indication and who did not have a hematological disease. Considering the adverse effects of anemia on growth and development, the diagnosis and treatment of even mild anemia has a vital importance.

Severe anemia was found in $5.6 \%$ of the patients. Chronic anemia (29.4\%) and malignancy (18.7\%) were the most common diagnoses of patients with severe anemia. Half of the patients with severe anemia were between 2-5 years of age. The age interval between 2-5 years, which is also called preschool age is a period where anemia is seen more frequently due to the fast growth, dependency on adults 
regarding nutrition and increased incidence of childhood cancers.

To sum up, anemia is a significant health problem during childhood. Collaboration between physicians and parents in the prevention and treatment of anemia is critical in protecting children from anemia, which is a reason of preventable mental retardation. The incidence of anemia in a reference centre in Black Sea region of Turkey is $8 \%$ among patients between $0.5-15$ years of age.

Ethics Committee Approval: Ondokuz Mayıs University Ethics Committee approval was obtained (2018/355 - 26.07.2018).

\section{Conflict of Interest: None.}

Funding: None.

Informed Consent: not considered since it is a retrospective document study.

Etik Kurul Onayı: Ondokuz Mayıs Üniversitesi Klinik Araştırmalar Etik Kurulu onayı alınmıştır (2018/355 26.07.2018).

Çıkar Çatışması: Yok Finansal Destek: Yok Hasta Onamı: Retrospektif dosya çalışması olduğu için gerekli görülmedi.

\section{REFERENCES}

1. World Health Organization. The Global Prevalence of Anaemıa in 2011. Geneva; 2015 Available from https://www. who.int/nutrition/publications/micronutrients/global_prevalence_anaemia_2011/en/

2. Kassebaum NJ, Jasrasaria R, Naghavi M, Wulf SK, Johns N, Lozano R, et al. A systematic analysis of global anemia burden from 1990 to 2010. Blood. 2014;123(5):615-24. https://doi.org/10.1182/blood-2013-06-508325

3. Sağlık Bakanlığı Ana Çocuk Sağlığı ve Aile Planlaması Genel Müdürlüğü. Demir Gibi Türkiye Projesi Genelgesi. Ankara, Turkey: Ministry of Health; 2009. Available from http:// www.saglik.gov.tr/extras/birimler/acsap/demir

4. Karagün BŞ, Korkmaz Ö, Gürsu AH, Cevit Ö, Solmaz S, Bayram $B$, et al. Sivas ilinde hastaneye başvuran 1-15 yaş grubu çocuklar arasında anemi prevalansı. Güncel Pediatri. 2014;2:67-72.

https://doi.org/10.4274/jcp.55264

5. Gür E, Yıldız I, Celkan T. Prevalence of anemia and the risk factors among school children in Istanbul. J Trop Pediatr. 2005;51:346-50. https://doi.org/10.1093/tropej/fmi032

6. Teziç T, Gedik Y, Kumandaş S. Trabzon merkez ve köylerinde 12-17 yaş grubu demir eksikliği prevelansı. (12-17 age group, the prevalence of iron deficiency in the center and the villages of Trabzon) Çocuk Hastalıkları ve Sağlığı Dergisi 1990;33:209-18.

7. Işık Balcı Y, Karabulut A, Gürses D, Ethem Çövüt I. Prevalence and Risk Factors of Anemia among Adolescents in Denizli, Turkey. Iran J Pediatr. 2012;22:77-81.

8. Güngör $O$, Albayrak D. Samsun ilinde 7-14 yaş arasındaki çocuklarda demir eksikliği ve demir eksikliği anemisi sıklığı, Prevalance of iron deficiency and iron deficiency anemia among 7-14 years old children in Samsun. İzmir Dr. Behçet Uz Çocuk Hast. Dergisi 2018;8(2):122-6. https://doi.org/10.5222/buchd.2018.122

9. World Health Organization. Haemoglobin Concentrations for the Diagnosis of Anemia and Assesment of Severity. Geneva; 2011 Available from https://www.who.int/vmnis/indicators/ haemoglobin/en/

10. Eren EÇ, Hatipoğlu S. Çocuklarda yaş gruplarına ve cinslerine göre anemi ve demir eksikliği anemisi sıklığının incelenmesi [master's thesis]. İstanbul: Bakırköy Dr. Sadi Konuk Eğitim ve Araştıma Hastanesi Çocuk Sağlığı ve Hastalıkları Klinik Bölümü; 2008. 